\title{
DEVELOPMENT STATUS IN EU BIOFUELS MARKET
}

\author{
Zuzana Kapustová*, Jaroslav Kapusta, Andrea Boháčiková, Peter Bielik
}

Slovak University of Agriculture in Nitra, Slovakia

The paper provides development status in the EU biofuel market by giving a comprehensive picture of production, consumption and production capacity of the first generation biofuels - biodiesel and bioethanol, while giving also insights into issues related to biofuel feedstocks such as crop production and harvested area. Development of crop production and harvested area for the crop products, used as a feedstock in the production of biofuels, have shown the changes in agriculture due to the growing trend of the biofuel sector. Additionally, the increasing production and consumption of biofuels may also affect the prices of agricultural commodities used as a feedstock for bioenergy production.

Keywords: agriculture; biodiesel; bioethanol; biofuels; European Union

Neuwahl et al. (2008) state that the promotion of biofuel use has been advocated as a means to promote the sustainable use of natural resources and to reduce greenhouse gas emissions originating from transport activities, as well as to reduce dependence on imported oil in order to increase security of the European energy supply. However, Ajanovic and Haas (2010) point out that despite the fact that on the one hand biofuels are expected to bring benefits like reduction of greenhouse gas emissions and increase of energy supply security, on the other hand, low effectiveness with respect to reducing greenhouse gas emissions and high costs are being criticized. Murnagham, K. (2017) emphasizes that the usage of renewables must be monitored and regulated in order to ensure the benefits are actualised; if left unregulated, the impacts on the environment can in some cases be worse than those arising from the use of fossil fuels.

The Renewable Energy Directive (2009/28/EC) requires that $20 \%$ of the EU's energy needs should come from renewable sources by 2020, and includes a target for the transport sector of 10\% from biofuels (Burrel, 2010), and raised the target to 14 percent in 2030 with advanced biofuels counting double to the target (Flach et al., 2019). The current EU policy for renewable energy is set in the EU Energy and Climate Change Package (CCP) and the Fuel Quality Directive (FQD). According to the EU's most recent biannual progress report (April 2019), the EU is on track to meet its 20 percent target and will likely meet the binding ten percent renewable energy target for the transport sector understanding that double-counting is used to achieve this target (Flach et al., 2019).

The aim of this study is to explore and review the EU's biofuels market by using the indicators of the production, consumption, and production capacity of the first-generation biofuels. Production of biofuels requires cultivation of the biofuel crops. Presently, most biofuels are produced based on conventional food and feed crops such as sugarcane, maize, and oil palm etc. (Ravindranath et al., 2009). This research will also take this by analysing crop production and harvested area for the crops used in the production of biofuels in the EU.

\section{Material and methods}

The study focuses on the analysis of the EU biofuel market giving a comprehensive picture of production, consumption and production capacity of biodiesel and bioethanol while also giving insights into issues related to biofuel feedstocks such as crop production and harvested area.

Data for the selected biofuel feedstock are taken from the FAOSTAT database and EU FAS Posts for the period 2004-2018, and indicators for the first-generation biofuels - bioethanol, biodiesel produced in the EU are drawn from EU FAS Posts.

The following steps are involved in conducting the paper: formulating the research question(s) and objective(s), searching the extant literature, screening for inclusion, assessing the quality of primary studies, extracting data, and analysing data (Templier and Paré, 2015). The method of theoretical generalization, statistical and comparative analysis as well as system analysis are applied in the paper.

\section{Results and discussion}

\section{Bioethanol}

The EU-28 is considered to be a less important producer of bioethanol on the world market in comparison to Brazil and the USA. At present, bioethanol is most often used as a fuel for cars in low-volume mixtures in the ratio of $10 \%$ ethanol and $90 \%$ petrol.

The evolution of bioethanol production, consumption, and production capacity in the EU between 2006 and 2016 are shown in figure 1. In 2009, bioethanol accounted for about $20 \%$ of total biofuels used in transport in the EU. The growing trend of production of this fuel is presented during each year in the observed period (figure 1). While the production of bioethanol was at the level of 1,633 million litres in 2006, the production was already at the level of 5,165 million litres in 2016. After an annual growth of approximately 600 million litres in 2008-2013, the growth rate is slowing down due to the decline in bioethanol consumption in Europe. The bioethanol industry in the EU was exposed to problems in 2010, 2011 and the first half of 2012, mainly due to excess production capacity on the market, weakening demand and competitive imports, especially from the United States. However, since 2013, competitive imports from the USA have decreased significantly. In 2014, the EU-28 almost reached the self-sufficiency of bioethanol due to increasing production and at the same because of time declining consumption. The declining consumption of bioethanol in 2014 had a negative impact on producers who were exposed to financial problems in the first half of 2015. In 2014, the industry benefited from low entry prices and restrictive measures on bioethanol imports, resulting in an increase in EU bioethanol production to around 5.3 billion litres. The domestic bioethanol market was affected by a declining domestic market in 2015, as petrol consumption was in decline and national blending mandates were adjusted downwards. 


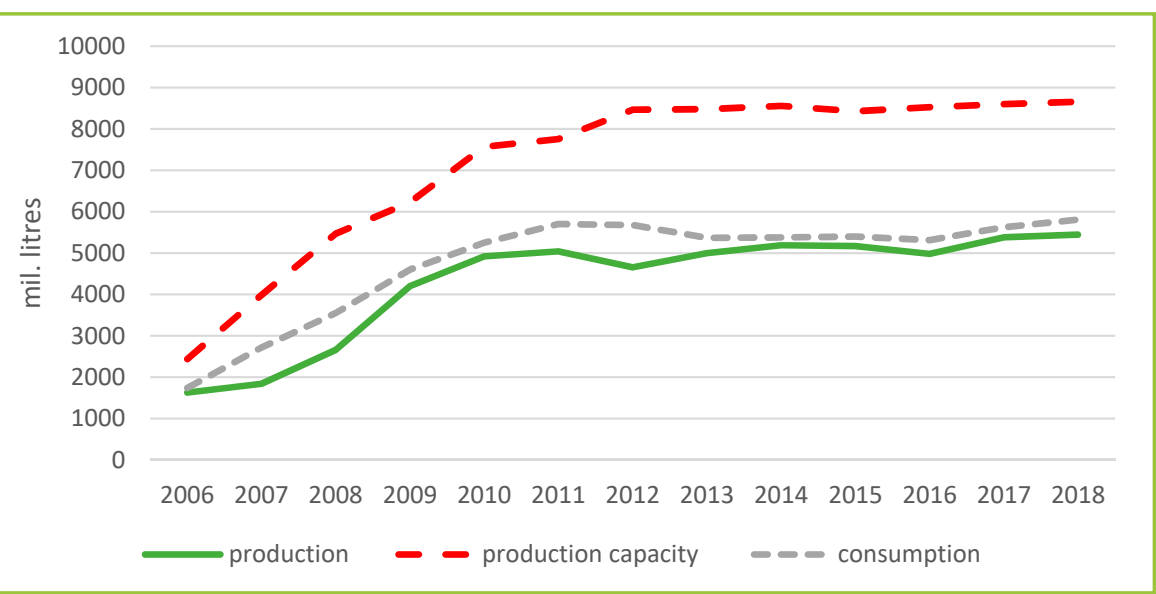

Figure 1 Production, production capacity and consumption of bioethanol in the EU Source: EU FAS Posts, authors' processing

Most bioethanol production capacity has been built in France, Germany, the United Kingdom, Spain, and Poland. Between 2007 and 2009 , only $60 \%$ of available production capacity in the EU was used. In 2007 and 2008, production capacity utilization was low due to high prices of cereals, especially wheat. Another reason for the under-utilization of production capacity was the competitive import of bioethanol from Brazil. EU28 ethanol production capacity has quadrupled from around 2.1 billion litres in 2006 to around 8.5 billion litres in 2013. Production capacity has not increased significantly since 2012 . The growth of bioethanol production capacity has been gradually declining since 2012 and this trend is expected to continue due to the gradual decline in first generation bioethanol production (figure 1).

France and Germany are among the most important producers of bioethanol from the EU28 in the long run (table 1). From other countries, we can also include Hungary in the category of main producers, where the bioethanol market has been expanding since 2010. In 2011, a new bioethanol refinery was completed in Hungary with the aim of processing approximately 500,000 tonnes of maize annually. Maize is mainly used as an input commodity to produce bioethanol in Hungary. About 80 percent of bioethanol production is exported. In the United Kingdom, production is increasing only due to the increased use of the existing capacity of the two plants. The United Kingdom recorded a shortage of about 600 million litres of bioethanol between 2011 and 2014.

In EU countries, bioethanol is mainly produced from wheat, maize, sugar beet, rye, and recycled oils. Wheat is used for bioethanol production mainly in North-western Europe, maize is used in Central Europe mainly in Hungary and Spain. In 2007 and 2008, grain prices were high, so that sugar beet was more favourable to produce bioethanol as a feedstock in this period. However, since the beginning of 2009, sugar prices have also risen due to limited world supply. As a result, bioethanol production from sugar beet increased only slightly. In 2013 and 2014, corn for ethanol production came mainly from Ukraine. While in 20060.39 thousand MT of maize was used to produce bioethanol, in 2016 it was 5.43 thousand MT (table 2).

Arable land is increasingly being used to produce biofuels in the EU. In France, for example, the share of maize, wheat and sugar beet production used for bioethanol is 7, 10 and 23 percent of total production, respectively. Since January 2015, Germany has changed its mandates to produce biofuels from energy to greenhouse gases (GHG). On January 1, 2017, the mandate was increased from 3.5 to 4 percent savings in

Table 1 Main producers of bioethanol in the EU (million litres)

\begin{tabular}{|l|c|c|c|c|c|c|c|c|c|c|c|c|c|}
\hline & 2006 & 2007 & 2008 & 2009 & 2010 & 2011 & 2012 & 2013 & 2014 & 2015 & 2016 & 2017 & 2018 \\
\hline France & 294 & 539 & 746 & 903 & 942 & 846 & 829 & 995 & 1,018 & 1,039 & 1,04 & 1,000 & 1,000 \\
\hline Germany & 430 & 397 & 580 & 752 & 765 & 730 & 776 & 851 & 920 & 937 & 935 & 852 & 776 \\
\hline Hungary & $\mathrm{x}$ & $\mathrm{x}$ & $\mathrm{x}$ & $\mathrm{x}$ & 190 & 190 & 291 & 392 & 456 & 589 & 598 & 633 & 645 \\
\hline Belgium & $\mathrm{x}$ & $\mathrm{x}$ & $\mathrm{x}$ & $\mathrm{x}$ & 315 & 400 & 410 & 451 & 557 & 570 & 570 & 620 & 645 \\
\hline Netherlands & $\mathrm{x}$ & $\mathrm{x}$ & $\mathrm{x}$ & $\mathrm{x}$ & 100 & 275 & 451 & 524 & 520 & 563 & 445 & 532 & 563 \\
\hline Spain & 405 & 359 & 346 & 465 & 471 & 462 & 381 & 442 & 453 & 494 & 328 & 377 & 522 \\
\hline United Kingdom & 0 & 44 & 359 & 346 & 352 & 89 & 215 & 278 & 329 & 538 & 660 & 684 & 684 \\
\hline Poland & 162 & 120 & 114 & 165 & 194 & 167 & 213 & 235 & 181 & 220 & 240 & 258 & 259 \\
\hline
\end{tabular}

Source: EU FAS Posts, authors' processing

Note: $x$-unavailable data

Table 2 Feedstock use for bioethanol (1,000 MT)

\begin{tabular}{|l|l|l|l|l|l|l|l|l|l|l|l|l|l|}
\hline & $\mathbf{2 0 0 6}$ & $\mathbf{2 0 0 7}$ & $\mathbf{2 0 0 8}$ & $\mathbf{2 0 0 9}$ & $\mathbf{2 0 1 0}$ & $\mathbf{2 0 1 1}$ & $\mathbf{2 0 1 2}$ & $\mathbf{2 0 1 3}$ & $\mathbf{2 0 1 4}$ & $\mathbf{2 0 1 5}$ & $\mathbf{2 0 1 6}$ & $\mathbf{2 0 1 7}$ & $\mathbf{2 0 1 8}$ \\
\hline Wheat & 1.35 & 1.34 & 1.62 & 2.31 & 3.77 & 4.45 & 3.29 & 3.2 & 3.59 & 3.73 & 3.99 & 5.18 & 5.61 \\
\hline Corn & 0.39 & 0.51 & 1.15 & 2.298 & 2.35 & 2.965 & 4.69 & 5.09 & 5.39 & 5.63 & 5.43 & 5.07 \\
\hline Sugar Beet & 3.08 & 5.37 & 9.44 & 10.08 & 9.12 & 9.47 & 10.6 & 11.6 & 10.0 & 8.8 & 9.78 & 8.33 \\
\hline Barley & 1.23 & 1.00 & 0.54 & 0.641 & 0.64 & 0.735 & 0.44 & 0.64 & 0.45 & 0.43 & 0.37 \\
\hline Rye & 1.03 & 0.65 & 0.72 & 0.95 & 1.11 & 0.69 & 0.4 & 0.79 & 0.84 & 0.77 \\
\hline
\end{tabular}

Source: $\quad$ EU FAS Posts, authors' processing 


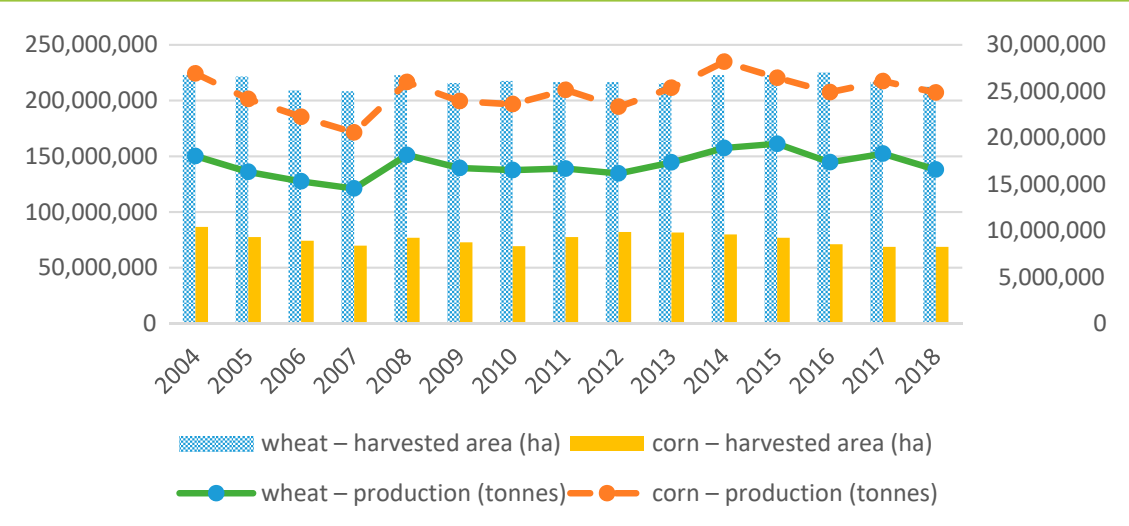

Figure 2 Production and harvested area of corn and wheat in the EU Source: FAOSTAT, authors' processing greenhouse gas emissions. This is expected to lead to an increase in the use of biofuels and increased demand will also benefit domestic bioethanol produced and imported. In Hungary, both capacity and production have expanded significantly over the last five years.

From a long-term perspective, production year-on-year declines. Increasing use of corn grain for biofuel production is becoming an important factor in the corn market. This growth has been reinforced by various government policy instruments to support biofuel production. In this context, it should be noted that the global production of corn may also be affected by the expected decline in harvested areas under corn in favour of wheat, or soybean, which is of interest in connection with the production of vegetable oils for human and industrial consumption (biofuel production). During the observed period, there is a slight increase in corn production. The EU reached the highest value of corn production in 2014 at the level of 77489654 tonnes (figure 2). of wheat recorded the growth without significant

\section{Biodiesel}

Unlike bioethanol, the European Union is the world's largest producer of biodiesel. Biodiesel was the first biofuel developed and used in the transport sector in the EU in 1990s (Flach et al., 2019). Johnson et al. (2010) explain that the reason why the EU biofuels market is driven by biodiesel rather than bioethanol is because of the high demand for diesel vehicles and the shortage of diesel compared with petrol.

From 2006 to 2009, the production capacity for biodiesel production increased significantly and the percentage increase in 2009 compared to 2006 reached a value of almost 360\%. After 2009, biodiesel production capacity grew at a slower pace until 2012. Since that year, also due to a reduction in biodiesel production in Germany and France, production capacity has been declining slightly. The declining interest in investing in biodiesel production capacity since 2009 is the result of difficult market conditions such as relatively low oil prices, high vegetable oil prices, rising imports, and the financial crisis. As a result,

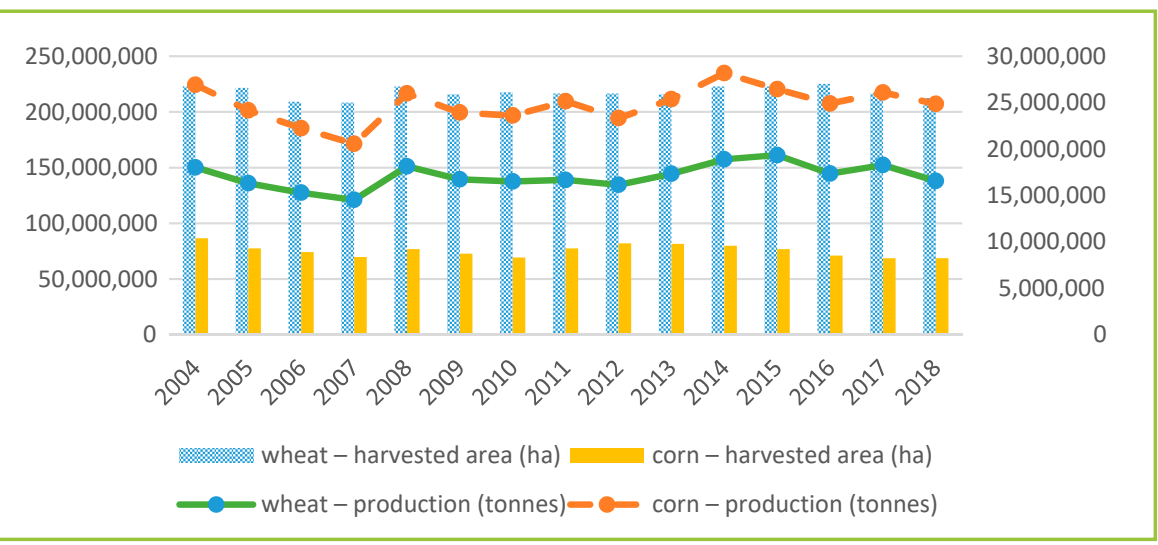

Figure 3 Production, production capacity and consumption of biodiesel in the EU Source: EU FAS Posts, authors' processing capacity consumption decreased from $52 \%$ in 2007 to $45 \%$ in 2011 (figure 3).

The structure of the biodiesel sector is very diverse, and the size of the facilities ranges from an annual capacity of 2,000 MT owned by a group of farmers to 600,000 MT owned by large multinational companies. EU biodiesel production is driven by domestic consumption and imported competition. Biodiesel production continued to increase in 2009 and was $9 \%$ higher than in 2008 (figrue 2). However, due to large stocks and high imports, the increase was lower than in previous years. In 2014, biodiesel production increased by $11 \%$, mainly in Germany, Spain, and the Netherlands. Double counting measures in some EU Member States and reduced mandates in Spain since 2013 have had a negative impact on demand and production in the EU. Also, expected lower imports, due to anti-dumping duties on biodiesel from Argentina and Indonesia in 2013 and 2014, stimulated biodiesel production.

In 2006, the three largest producing EU Member States (Germany, France, and Italy) produced $76 \%$ of total EU biodiesel production (table 4). In 2008, the share of production of the first three producing EU Member States (Germany, France, and the Benelux) fell to $66 \%$. The recovery of Spanish production is a combination of factors which include countervailing duties imposed on imports of biodiesel originating in Argentina and Indonesia and, to a lesser extent, the introduction of a system of production quotas in Spain.

Europe is one of the largest producers of biodiesel in the world and uses oil crops as a raw material to produce biodiesel, especially oilseed rape. The development of cultivation areas and thus the production of oilseed rape is greatly influenced by international trends confirming the growing demand for organic food and renewable energy sources. During the period under review, a significant increase in rapeseed production was recorded. While the production of this crop in Europe in 2004 amounted to 16138195 tonnes, in 2014, it was almost double, and the production reached the value of 28769012 tonnes. In 2011, also due to the widespread drought in Germany, production fell by about $7 \%$ compared to 2010. The production of oilseed rape recorded 19974567 tonnes in 2018, which represented an increase of 4473139 tonnes in comparison to 2004 (figure 4).

In the long run, Germany is the largest oilseed rape producer in Europe, with production of 5,016,800 tonnes in 2015. The largest increase in rapeseed production was achieved by France; while in 2004 the production reached the level 


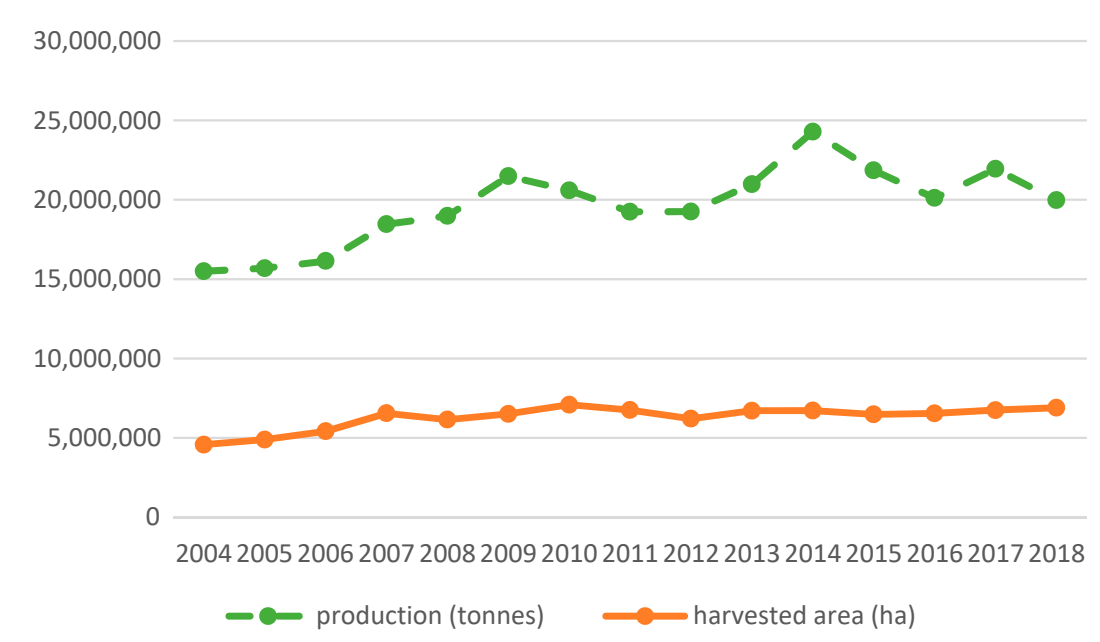

Figure 4 Production and harvested area of oilseed rape in the EU Source: FAOSTAT, authors' processing of 3,997,897 tonnes, in 2015 the production was almost 33\% higher at the level of 5,334,404 tonnes (table 3).

Rapeseed oil is the main raw material for biodiesel production in the $\mathrm{EU}$, accounting for about two thirds of total biodiesel production in the EU. However, since 2012, the share of rapeseed oil as a feedstock for biodiesel production has been gradually declining due to the higher use of palm oil and recycled vegetable oil (RV0). Most soybean oil is used as an input commodity in Spain and France. Recycled vegetable oils and animal fat have not been among the most popular raw materials in the past in comparison to vegetable oils (table 5). However, with high vegetable oil prices at the end of 2007 and in the first half of 2008 , they created a cheaper alternative of raw material and consequently, their usage increased. RVOs (recycled vegetable oils) ranked third among

Table 3 The most important producers of oilseed rape in EU (tonnes)

\begin{tabular}{|l|c|c|} 
& 2004 & 2015 \\
\hline Germany & 5276589 & 5016800 \\
\hline France & 3997897 & 5334404 \\
\hline United Kingdom & 1606834 & 2542000 \\
\hline Poland & 1632949 & 2700776 \\
\hline Czech Republic & 934674 & 1256212 \\
\hline Spain & 8760 & 149198 \\
\hline
\end{tabular}

Source: FAOSTAT, authors' processing

Table 4 Main producers of biodiesel in the EU (Million litres)

\begin{tabular}{|c|c|c|c|c|c|c|c|c|c|c|c|c|c|}
\hline & 2006 & 2007 & 2008 & 2009 & 2010 & 2011 & 2012 & 2013 & 2014 & 2015 & 2016 & 2017 & 2018 \\
\hline Germany & 2.7 & 3.28 & 3.25 & 2.6 & 3,181 & 3,408 & 3,106 & 3,307 & 3,808 & 3,505 & 3,522 & 3,644 & 3,100 \\
\hline France & 0.65 & 1.09 & 2 & 2.61 & 2,27 & 2,09 & 2,516 & 2,476 & 2,681 & 2,556 & 2,522 & 2,181 & 1,700 \\
\hline Italy & 600 & 530 & 760 & 900 & 908 & 704 & 326 & 521 & 452 & 625 & 398 & 599 & 568 \\
\hline Spain & 0.14 & 0.17 & 0.28 & 0.7 & 1,041 & 787 & 538 & 659 & 1,016 & 1,103 & 1,319 & 1,721 & 2,000 \\
\hline The Netherlands & $x$ & $x$ & $x$ & $x$ & $x$ & 558 & 974 & 790 & 1,056 & 795 & 638 & 1,116 & 1,100 \\
\hline Poland & $x$ & $\mathrm{x}$ & $\mathrm{x}$ & $x$ & $x$ & 414 & 673 & 736 & 786 & 861 & 985 & 1,019 & 1,000 \\
\hline
\end{tabular}

Source: EU FAS Posts, authors' processing

Note: $x$-unavailable data

Table 5 Feedstock use for biodiesel in EU (1,000 MT)

\begin{tabular}{|c|c|c|c|c|c|c|c|c|c|c|c|c|c|}
\hline & 2006 & 2007 & 2008 & 2009 & 2010 & 2011 & 2012 & 2013 & 2014 & 2015 & 2016 & 2017 & 2018 \\
\hline Rapeseed oil & 3.71 & 4.23 & 6.04 & 6.05 & 6.7 & 6.1 & 6.1 & 5.75 & 6.1 & 6.38 & 6.14 & 6.30 & 5.20 \\
\hline Soybean oil & 0.57 & 0.83 & 0.96 & 1.05 & 1.085 & 0.95 & 0.74 & 0.86 & 0.89 & 0.59 & 0.62 & 0.93 & 1.000 \\
\hline Palm oil & 0.28 & 0.39 & 0.6 & 0.66 & 0.69 & 0.7 & 1.43 & 2 & 1.58 & 2.6 & 2.4 & 2.65 & 2.67 \\
\hline Sunflower oil & 0.03 & 0.07 & 130 & 170 & $x$ & 100 & 300 & 290 & 310 & 210 & 250 & 180 & 185 \\
\hline UCO & $x$ & $x$ & $x$ & $x$ & $x$ & 680 & 760 & 1,1 & 1,91 & 2,27 & 2,44 & 2,770 & 2,860 \\
\hline
\end{tabular}

Source: EU FAS Posts, authors' processing

Note: $x$-unavailable data 
raw materials used for biodiesel production in 2014. The United Kingdom, the Benelux and Germany belong to the largest producers of RVOs in the EU-28. In 2016, palm oil was the second most important raw material. Its usage has further increased mainly due to its use to produce hydrogenated vegetable oil (HVO). Currently, palm oil is used mainly in Spain, the Netherlands, Finland, Italy, and France, and to a much lesser extent in Germany, Portugal, Romania, and Poland.

\section{Conclusions}

The Member states of the EU focus mainly on the production of biodiesel, which is produced in a ratio of 80:20 compared to bioethanol. Biofuel production in the EU is marked by meeting the $10 \%$ share of biofuels in total fuel consumption by 2020. Nevertheless, biofuel production has started to stagnate since 2012 and stagnation is expected to continue in the near future due to quota adjustments in favour of second-generation biofuels. The stagnation, recorded in the production of biofuels, was also caused by other several factors, such as cheaper imports of biofuels from overseas countries, quota adjustments as well as low oil prices during the examined period. It is expected that the revised Directive (Renewable Energy Directive (2009/28/EC)) will cause a decline in the production of first-generation biofuels and strengthen the production of second-generation biofuels. Bioethanol production capacity is used at around $60 \%$ and significant further capacity building is not expected soon. From the input raw materials used in the production of biodiesel, recycled vegetable oils (UCO) have been used significantly since 2015. In 2016, UCO represented (after rapeseed oil) the second most used raw material entering the biodiesel production process. Within the EU-28, Germany and France represent the leading countries in biofuel production in the long run. Since 2004, the largest boom in biofuel production has been recorded in Spain, the Benelux countries and, from Central European countries, in Hungary.

Popp et al. (2014) mention that first generation transport biofuels, for example, biodiesel based on oilseed rape or ethanol from wheat/maize, are characteristic with far less efficient use of resources. Therefore, a broader mix of crops could reduce environmental impacts since the current energy crop mix in the EU is not favourable to the environment. Babcock (2008) explains that expansion of biofuel production in Europe has coincided with sharp increases in prices for food grains, feed grains, oilseeds, and vegetable oils and the credibility of the association of high food prices with expanded biofuel production is also heightened by the fact that practically all biofuels in the world are produced from feedstocks that could be used to produce food or that are produced on land that could produce food. Eisentraut (2010) points out that the increasing criticism of the sustainability of many first-generation biofuels has raised attention to the potential of so-called second-generation biofuels, because their production has the potential to provide benefits such as consuming waste residues and making use of abandoned land. However, their production could become unsustainable if they compete with food crops for available land.

\section{Acknowledgements}

This paper is supported by the project VEGA no. 1/0338/18 with the title Impact of the Common Agricultural Policy on the mitigation of income risk in Slovak agriculture and factors determining the level of risk of agricultural companies.

\section{References}

AJANOVIC, A. - HAAS, R. 2010. Economic challenges for the future relevance of biofuels in transport in EU countries. In Energy, vol. 35, 2010, no. 8, pp. 3340-3348 DOl: 10.1016/j.energy.2010.04.020.

BABCOCK, B.A. 2008. Breaking the Link between Food and Biofuels. Briefing Paper 08-BP 53. Iowa : lowa State University, 2020. From: https://www.card.iastate.edu/products/ publications/pdf/08bp53.pdf

BURRELL, A. ed. 2010. Impacts of the EU Biofuel Target on Agricultural Markets and Land Use - A Comparative Modelling Assessment. JRC Working Papers. Luxembourg : Publications Office of the European Union, 2010. D0I: 10.2791/45105.

EISENTRAUT, A. 2010. Sustainable Production of Second-Generation Biofuels: Potential and Perspectives in Major Economies and Developing Countries. In IEA Energy Papers, 2010, no. 1. D0I: 10.1787/5kmh3njpt6r0-en.

FLACH, B. - LIEBERZ, S. - BOLLA, S. 2019. EU Biofuels Annual 2019. Retrieved September 20, 2020. From: https://apps.fas.usda.gov/newgainapi/api/report/downloadreportb yfilename?filename=Biofuels\%20Annual The\%20Hague EU-28 7-15-2019.pdf

FOOD AND AGRICULTURE ORGANIZATION OF THE UNITED NATIONS. (2012). FAOSTAT Database. Rome, Italy : FA0.FAOSTAT statistical database. Retrieved September 30, 2020. From: http://www.fao.org/faostat/en/\#data/QC

JOHNSON, F.X. - PACINI, H. - SMEETS, E. 2012. Transformations in EU biofuels markets under the Renewable Energy Directive and the implications for land use, trade and forests. Bogor, Indonesia : CIFOR, 2012, occasional paper 78.

MURnAGHAM, K. 2017. A Comprehensive Evaluation of the EU's Biofuel Policy - from biofuels to agrofuels. Berlin : Institute for International Political Economy (IPE), working paper, 2017, no. 81. Retrieved September 10, 2020. From: https://www. econstor.eu/bitstream/10419/149890/1/878094121.pdf

NEUWAHLA, F. - LÖSCHEL, A. - MONGELLI, I. - DELGADO, L. 2008. Employment impacts of EU biofuels policy: Combining bottom-up technology information and sectoral market simulations in an input-output framework. In Ecological economics, vol. 68, 2008, no. 1-2, pp. 447-460. D0I: 10.1016/j.ecolecon.2008.04.018.

POPP, J. - LAKNER, Z. - HARANGI-RÁKOS, M. - FÁRI, M. 2014. The effect of bioenergy expansion: Food, energy, and environment. In Renewable and Sustainable Energy Reviews, vol. 32, 2014, pp. 559-578. D0l: 10.1016/j.rser.2014.01.056.

RAVINDRANATH, N.H. - MANUVIE, R. - FARGIONE, J. - CANADELL, P. - BERNDES, G. WOODS, J. - WATSON, H. - SATHAYE, J. 2009. GHG Implications of Land Use and Land Conversion to Biofuel Crops. In Howarth, R. and Bringezu, S. (eds) Biofeuls: Environmental consequences and interactions with changing land use. Proceedings of the Scientific Committee on Problems of the Environment (SCOPE) International Biofuels Project Rapid Assessment, Gummersbach Germany : Cornell University, NY, USA, 22-25 September 2008, pp. 111-125.

TEMPLIER, M. - PARÉ, G. 2015. A framework for guiding and evaluating literature reviews. In Communications of the Association for Information Systems, vol. 37, 2015, no. 6, pp. 112-137.

UNITED STATES DEPARTMENT OF AGRICULTURE. Foreign Agricultural Service. EU-28: Biofuels Annual. Retrieved September 15, 2020. From: https://www.fas.usda.gov/ data/eu-28-biofuels-annual-1

\section{Contact address}

Zuzana Kapustová, Slovak University of Agriculture in Nitra, Faculty of economics and management, Department of economics, Tr. Andreja Hlinku 2, 94976 Nitra, Slovakia, e-mail: zuzana.lajdova@gmail.com 